\title{
EXAMINATION OF CRISIS RESPONSE PREPAREDNESS IN LISTED JOINT-STOCK COMPANIES IN THE REGION
}

\author{
Miloš Grujić \\ Republic of Srpska Pension reserve fund management company \\ gruja84@gmail.com \\ Perica Rajčević \\ Vodovod a.d. Banjaluka \\ prajcevic77@gmail.com
}

\begin{abstract}
As a consequence of the measures taken to remedy the medical problem, there may be a bigger one economically, all over the world. The paper analyzes the consequences of the current economic crisis caused by the COVID-19 virus pandemic. The key economic consequences of the pandemic for companies but also for the economy have been identified. Entrepreneurs, small and medium enterprises, with the smallest liquidity stocks, are expected to feel the greatest consequences of the economic crisis. Taught by the failures of the Great Depression and the relative successes of the crisis in 2008, governments have already announced and launched massive programs to help businesses. At this moment, the supply of liquidity of deficient economic entities is a critical issue. The previous crisis showed that governments have tried and tested mechanisms for supplying liquidity to the financial sector, but transmission mechanisms to end-users were the Achilles' heel of the mechanism. We believe that success in finding adequate channels for the transfer of liquidity to economic entities with a liquidity deficit will be crucial for the character, length, and depth of the crisis. The paper offers a number of proposals for key necessary measures at the state level to overcome the observed economic disruptions. One of them is the request of the regulator, the other is the reaction of the state, but an important part must also come from the company. In addition, the research conducted by the questionnaire method for joint-stock companies from the Western Balkans resulted in a set of measures that serve as a basis for determining the gap in the required and current set of measures taken at the level of an individual organization.The aim of this paper is to point out that in the short term it is possible to stabilize the system through the application of macroeconomic and microeconomic measures.
\end{abstract}

Keywords: COVID-19, financial management, financial crises, economic development, business fluctuations

JEL classification:E60, F60, G32

\section{INTRODUCTION}

Since the beginning of this millennium, the world has been hit by the outbreak of several dangerous virus pandemics: SARS from 2002 until 2003 (death toll:770); 2009-2010 Swine flu (200,000 death cases); MERS 2010 - still not eradicated (850 death cases); 2014-2016 Ebola (death toll:11,300). This year, 2020, the world has seen a pandemic caused by a new, mutated version of the SARS virus, coronavirus (LePan, March 14, 2020). What is specific about this virus is that it is highly contagious, whereas its mortality rate, according to some estimates, is up to ten times higher in comparison with the seasonal flu. The number of infected and sick persons changes every day. According to the latest data, a total of 4,032,763 infected people have been registered in a period of about five months, 276,677 (7\% mortality rate) have died until now, while 1,399,718 have recovered (Worldometers, 2020; Hopkins, 2020).

http://doi.org/10.47063/EBTSF.2020.0009

http://hdl.handle.net/20.500.12188/9684 
In the month of March, which was the most critical month, the transmission rate of coronavirus was terrifying. The Australian professor of economics, Steve Keen, at that time gave the estimate that a number of infected people doubled every six days. Under such circumstances, if the infection had continued to spread at such a rate, with only registered cases taken into account, "the entire planet would have become infected within three months" (Zec \& Radonjić, 2020).

On the other hand, restrictive measures certainly lead to major economic problems according to some authors, in case the pandemic does not last for too long, a combination of expansionary monetary policy (interest rate cuts) along with fiscal stabilizers should be sufficient to address this crisis, the recovery from which, similar to what has happened with the 2003 SARS pandemic, would be "V"-shaped (Sell, 7.4.2020). Contrary to this, should the crisis pursue to exist and should it erupt again in the fall, production chains and profit margins would be seriously jeopardized. In the latter case, apart from the policy of lowering referential interest rates, central banks might be forced to pump liquidity into the system whereas fiscal authorities would have to significantly increase their spending and make huge efforts to further stimulate free market flows and foreign investment. The recovery would then be "U"-shaped (OECD, 2.3.2020).

Figure 1. Real world GDP growth rate (in\%)

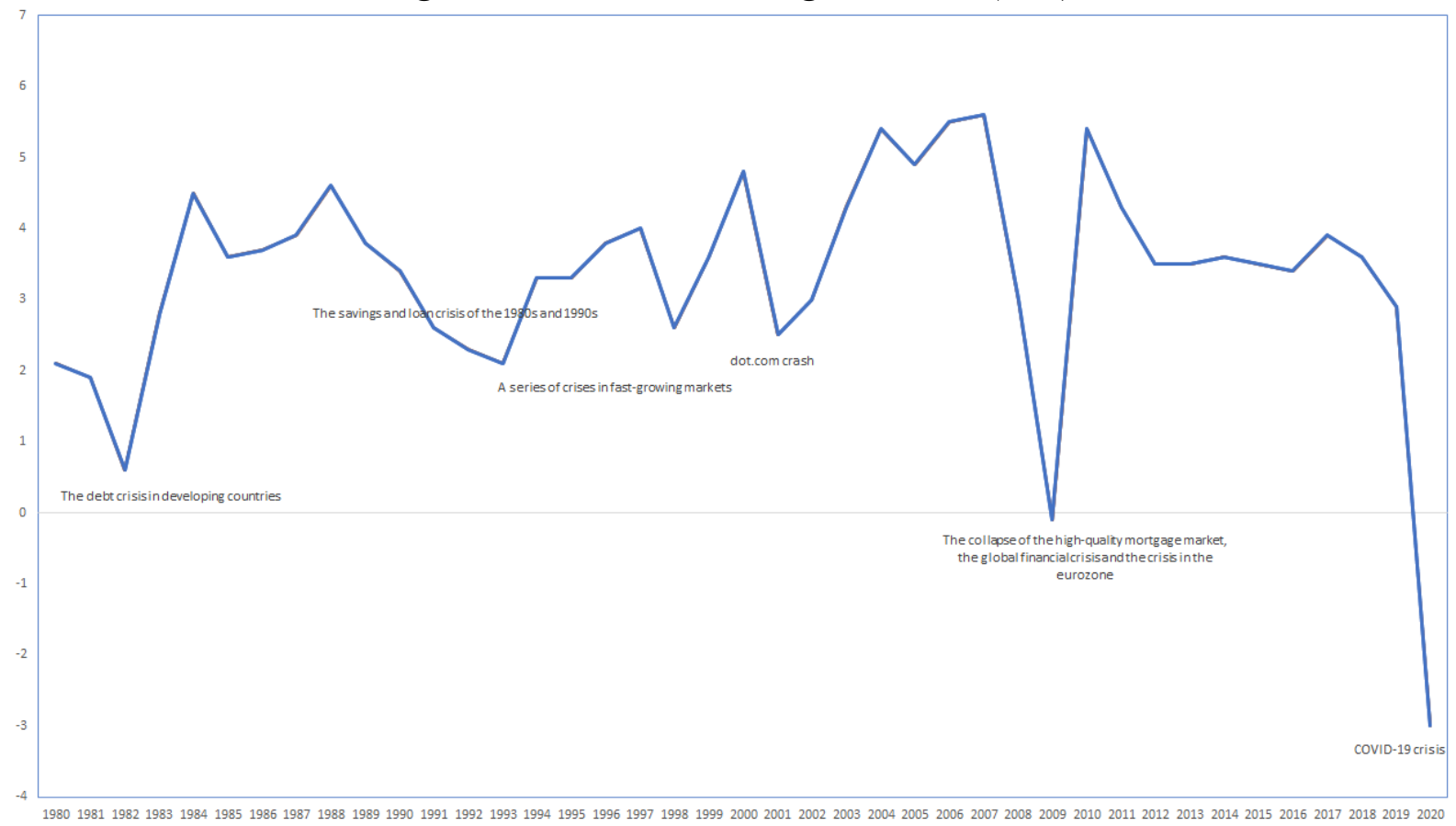

Source: World Economic Outlook Database (April 2020). Note: estimates are given for 2019 and 2020.

The impacts of the crisis manifest themselves through a financial performance decline, jeopardized liquidity, and impaired financial stability of companies. When the crisis grows from a tactical to a deep strategic crisis, the consequences become far more radical and can lead to bankruptcy and liquidation of a company.Based on what was said above, the detection of early crisis signals can have a determining influence on the scope of the damage caused, whereas the flexibility of the crisis plan and the comprehensiveness of crisis measures may contribute to the effectiveness of implemented activities for mitigating the consequences. Given the depth of the current crisis, the measures taken at the level of an individual company are not sufficient to achieve the desired result. The deep economic crisis caused by 
the COVID-19 virus pandemic requires crisis management both at the state level and at the organizational level.

There is no doubt that everyone will have a need for liquidity. The cash holdings or investment into the quickly marketable securities proved to be a wise strategy. The first step in defining crisis measures is to analyze the current situation where the consequences of the crisis would be identified so that its causes could be mitigated and eliminated.

\section{CONSEQUENCES OF THE GLOBAL COVID-19 PANDEMIC}

The proportions of the global crisis caused by the COVID-19 pandemic still cannot be fully comprehended. It is evident that the damage inflicted on the economy already exceeds the effects of the global financial crisis from 2008, and some sources claim that the crisis is even worse than the Great Depression (Roubini, 2020; Chan, 2020). These two crises were accompanied by a $50 \%$ decline in financial markets, a contraction in demand, freezing of credit-related activities, accelerated unemployment growth, a significant decline in gross domestic product, a rapid corporate profit decrease, and the final outcome was the bankruptcy of numerous companies. Local economies have been affected to a greater or lesser extent, but in general, due to the global interconnection, the economy has suffered extremely high losses in a very short time and is facing a potential recession in the coming quarters. Also, this economic crisis is specific for the fact that it has not been caused by economic factors and that nothing of a kind has been described in economic books and textbooks. So far, there is even no consensus on whether this is a supply shock, a demand shock or asymmetrical shock of both. At the moment there is only a consensus that the virus-induced crisis will most likely be the catalyst of a large-scale financial crisis.

Payment limitations and a slowed process of settling obligations launched an avalanche of illiquidity that is spreading at a high speed throughout the entire economic system. In addition to that, many companies have optimistically initiated new investment cycles encouraged by the preceding period of prosperity, where this has clearly strained their liquidity position.

Following initial estimates, some businessmen have made one-month crisis plans, only a few have developed plans covering a two monthperiod, and almost non created crisis plans for the coming year. Undoubtedly, the effects described so far will continue to affect liquidity until the end of this year as a result of the measures taken by the governments of some countries. For example, the Government of Hungary imposed a moratorium on loan repayments for businesses and citizens until the end of the year.

The greatest pressure of the current crisis will be experienced by entrepreneurs, micro, small and medium enterprises. Given a high level of participation of the mentioned sector in economic activities, their preservation in times of crisis becomes one of the major tasks of authorities. The consequences of the crisis will be reflected in reduced employment in this sector and in the bankruptcy of a large number of entrepreneurs and micro-enterprises. In the state of "hibernating economy", it is not going to be possible to provide for the salaries from the current reduced cash inflow and from accumulated reserves, therefore social (and security) tensions will rise proportionally to the duration of the entire situation and to the reduction of personal savings of dismissed employees. Milanović argues that one of the key dangers of this pandemic is a social collapse, and that one can expect a large number of dissatisfied people who will see themselves as unjust losers in this pandemic (Milanovic, 2020).

Furthermore, the banking sector is under great pressure. There is a liquidity outflow from the banking system due to the irrational funds withdrawal by the citizens and by the economy as a result of uncertainty, fear among the population, the urge to use accumulated reserves and 
to save the cash for the "rainy days". Apart from that, as a consequence of the moratorium and the inability to ensure new loans, banks will have to seek external liquidity support.

Also, the cost-benefit analysis will show that in certain economic areas, it might be more profitable to initiate deliberate bankruptcy and liquidation of the company. More specifically, it could happen that the company owners might withdraw liquid assets and declare bankruptcy, using the entire economic situation as an alibi for their bad business results, and thus preserving their reputation. In addition to the closure of these companies, we could expect a high risk of bankruptcy of associated companies in the value chain of such companies.

Taking into account those negative trends, the seriousness of the situation and the potentially devastating effects of the pandemic on the economy of all countries, it is of utmost importance to adopt a package of coordinated and comprehensive measures to support business entities in order to overcome the already present and evident liquidity crisis rising. In addition to state measures, the measures at the level of individual companies are also required.

\section{PROPOSAL OF STATE MEASURES TO OVERCOME THE CRISIS}

Based on the lessons learned on the failures in tackling the Great Depression and on the relative successes in addressing the Great Repression in 2008, governments have already announced and launched massive aid programs for businesses. At this moment, the liquidity supply in deficient business entities seems to be an essential issue. The previous crisis showed that the governments had at disposal already implemented and tested mechanisms for liquidity supply in the financial sector, but the mechanisms of transmission towards the endusers proved to be a sort of the Achilles' heel of such mechanisms. We believe that success in searching for adequate channels for the transfer of liquidity towards businesses facing a liquidity deficit will be crucial for the characteristics, length and depth of the crisis. All the measures introduced and announced until now, first of all the moratorium on loans and certain fiscal policy measures, represent a partial relief for business entities. However, in the current situation, characterized by the paradigm of a dramatic drop in turnover, i.e. profit, and then in the cash inflow, state measures will be far from enough. In principle, if we keep in mind a very low level of liquidity reserves in the economy, especially in the segment of small and medium enterprises, the total absence of inflow in a short period of time leads to a situation where there is a lack of financial means to cover basic operating costs, primarily those related to wages, suppliers and taxes. Following the economic logic, companies will start reducing all controllable costs very soon.

With this in mind, it is necessary to decide about urgent measures aimed at the emergent increase of economic liquidity, the implementation of which would have to be inevitably rapid so that the first bankruptcy and dismissal wave could be avoided. All measures taken by the German Government and Bundestag account for $10 \%$ of German GDP. ${ }^{1}$ Spanish authorities announced measures worth 200 billion euros to help the economy, the Portuguese Government adopted a package of economic measures in the amount of 9.2 billion euros, and the French Government provided 60 billion euros worth funds to help SMEs ${ }^{2}$. So far, the package of measures to help the economy with the highest value has been the one announced

\footnotetext{
${ }^{1}$ Available at: https://www.ft.com/content/dacd2ac6-6b5f-11ea-89df-41bea055720b. Page visited on: 07.04.2020.

${ }^{2}$ Available at: https://www.dw.com/en/coronavirus-what-countries-are-doing-to-minimize-economic-damage/a52816921. Page last visited on: 07.04.2020.
} 
by the United States, worth more than one trillion euros ${ }^{3}$. The described packages should be directed towards entrepreneurs, micro, small and medium enterprises, regardless of the economic branch in which they operate, as well as towards large enterprises that are directly affected by the current crisis.

When approving emergency liquidity loans, it is necessary to additionally specify and clarify the criteria. One of the basic conditions for approval is a non-discriminatory approach, i.e. the absence of customer favoring by commercial banks. On the other hand, in order to ensure the general economic stability, the clients must commit themselves not to reduce the number of employees for a minimum period of six months, to ensure regular payment of wages, of public revenues and to make duly and regular payment of obligations towards suppliers. Furthermore, credit requirements should be as simple as possible with an aim of quick approval and in line with the minimum acceptable criteria unique for all commercial banks: that the client's account has not been blocked prior the state of emergency, that certain standard criteria measurable by ratio indicators have been fulfilled and the like. At the same time, loans must be made available for those companies that are not currently in debt, because at the moment they have no benefit from the already implemented moratorium measures. Most importantly, there must be zero tolerance towards the non-payment of state duties since it is imperative to strengthen the tax discipline. So, the world is to face two drivers of recession, the first being a pandemic and the second, the subsequent one, being a typical financial recession caused by a collapse of credit markets and confidence that could easily turn into a recession on balance sheets should reactions fail to provide adequate success in the first, liquidity step, and in the second, investment reviving step.

State level decisions are not easy to make, and they require coordinated calculations of implications by central banks and Ministries of Finance. It is important to highlight that partial and delayed measures or the absence of additional measures undoubtedly lead to the economic liquidity collapse, and this could launch irreversible structural effects in the coming period. A coherent set of previously proposed measures, quickly implemented, will ensure the necessary liquidity and reduce to an extent the fear of non-payment produced by the effects of the economic system freezing. If we take a look at the comparative practice, i.e. the world's largest economies, we can draw a conclusion that the focus of economic measures is on increasing the liquidity of the economy, which in turn protects the liquidity of the state and maintains social peace in it. Rapid implementation of measures is crucial in order to use the existing reserves capacities for creating a reaction. With the passage of time and the reduction of reserves, the response ability of the state will be smaller and smaller, and the effectiveness of economic aid will be lower and lower. To ensure a quick response, complicated bureaucratic procedures have to be avoided.

\section{IDENTIFYING CRISIS MEASURES GAP AT THE COMPANY LEVEL}

Big companies and financial sector companies have crisis plans pre-prepared and crisis teams pre-formed, the main role of which is to implement pre-prepared plans when the crisis emerges. However, a pre-formed crisis team is not necessarily a guarantee of a quality and quick response to the crisis. Augustine (1995) argues that crisis teams are not of great use in crisis situations if they have never been tested before. Mitroff, Harrington, and Gia (1996) specifically accentuate that the crisis team training is extremely important for the team members to be able to make quick and quality decisions once a real crisis emerges.

\footnotetext{
${ }^{3}$ Available at: https://www.cnbc.com/2020/03/23/trump-fed-congress-government-efforts-to-containcoronavirus-economic-impact.html. Page last visited: 07.04.2020.
} 
On the other hand, it is necessary to highlight that the entrepreneurs, small and many medium-sized enterprises lack in sufficient human, organizational and financial capacities, as well as in experience that would enable them to be prepared for the anticipated crisis and to offer a systematic response. In a time of deep economic crisis, which the current crisis caused by the COVID-19 pandemic is, all crisis measures, regardless of the size of the company, should be directed at survival in the short period of time and at the preservation of stability so that the companies could continue their business when the acute crisis ends.

A crisis management plan, by its nature, is a set of guidelines and not a fully precise action plan given that no single crisis shares identical symptoms and consequences with any other. Authors Barton (2001), Fearn-Banks (2001) and Coombs (2007) claim that a crisis plan saves time when the crisis appears because it proactively defines team members' tasks, provides necessary information and guidance for action.

Once the first crisis consequences are manifested, it is necessary to make a quick reaction in the form of crisis measures that should prevent a bigger negative impact. Carney and Jorden (1993) point out that a speedy response means that the organization is active and that it is in control of the current situation. A similar conclusion was reached by the authors Arpan and Rosko-Ewoldsen (2005) who argue that a rapid and early response to a crisis enables a company to gain and maintain great credibility among its stakeholders.

However, it is very common in business practice that the focus of the management at the time of crisis is directed only on finances and financial indicators, because the consequences of the deep economic crisis are effected precisely through a drastic drop in income and profitability indicators. In such circumstances, when there is a high degree of uncertainty, an integrated approach to crisis planning is entirely neglected and many business areas remain outside the reach of crisis management. In order for crisis management and crisis planning to have a positive effect, it is necessary to take an integrated approach to crisis planning and to expand the focus from finances to other related business areas.

In this context, it is necessary to identify a comprehensive gap in crisis management practices and recognize neglected crisis areas. The management team, based on the recommended selfassessment questions, is able to make a quick and easy test of the implementation of existing crisis management practices in the areas of finance, leadership and organization, human resources, marketing and sales, communication, procurement and logistics, production and law.

\section{METHODOLOGY}

The research was conducted by the survey research method. Managers in joint-stock companies listed on stock exchanges in the region were surveyed: Banja Luka Stock Exchange (companies from the entity Republika Srpska), Sarajevo (companies from the entities Federation of Bosnia and Herzegovina), Montenegro Stock Exchange, Belgrade Stock Exchange, Zagreb Stock Exchange, Macedonian Stock Exchange, Budapest Stock Exchange, and Ljubljana Stock Exchange. For the most part, the sample includes nonfinancial companies that were or are still part of the main stock exchange index and that paid dividends (Table 1). The questionnaires were submitted electronically, in the form of a form, during May 2020. The process of collecting survey questionnaires was completed on June 4, 2020. The tendency was to include a sample of at least a double-digit percentage of listed joint-stock companies. Responses were obtained to 125 of the 164 questionnaires sent. The rate of return should be attributed to the relatively small number of respondents, but also to the long period of conducting the survey, which is why, in addition to sending questionnaires, it was possible to contact respondents and encourage them to cooperate. 
The questions were taken from the author Lončar \& Stojanović (2020) with certain modifications by the author. Lončar and Stojanović presented a set of questions from eight business areas that serve as a basis for determining the gap in the necessary and current set of measures taken for crisis management at the level of an individual organization. Issues are in the areas of finance, leadership, and organization, human resources, marketing and sales, communications, procurement and logistics, manufacturing, and law. The authors did not state whether certain answers should be accompanied by specific weight. Selected and refined questions that were used in the research, ie sent in the form of an electronic questionnaire are:

1. Have you made an analysis of different financial scenarios in business?

2. Have you made a financial risk register by the time the pandemic is declared?

3. Have you made a cash flow plan on a daily, weekly, and monthly basis?

4. Have you analyzed the portfolio of current investment projects and determined the priorities and the possibility of postponing individual projects?

5. Have you done a detailed financial stress test?

6. Have you singled out key goals and success indicators for the crisis period?

7. Have you clearly defined your priorities in the crisis period and directed all employees to work in this direction (are employees informed about priorities)?

8. Have you determined which level of operations in each of the business functions of the company is considered the minimum level of maintenance of the work process?

9. Have you defined a model for ensuring business continuity in case of operational risks (eg main server shutdown, power outage, breakdowns, and other escalations)?

10. As a direct consequence of the pandemic, were you forced to lay off employees?

11. Do you think that you will have to reduce the number of employees by the end of the year?

12. Do all employees have clear instructions on how to function during the crisis?

13. Have you considered alternatives to permanent employment (eg alternating unpaid leave, collective leave, dismissal of temporary and occasional workers, etc.)?

14. Have you analyzed contracts with workers and identified the risks that may arise in the case of some employment activities on your part?

15. Have you assessed the risk of leaving some key employees during or after the crisis?

16. Have you backed up all relevant data?

The obtained research results contain the following risks, ie limitations of the conducted research: respondents who participated in the research are not representative representatives of the sample companies, respondents misunderstood the questions asked, after completing the questionnaires there was a change of attitudes among respondents, and respondents individuals could not complete the questionnaire twice but were until June 4th could correct the answers offered. The collected data were subjected to statistical analysis. 
Table 1: Data on the sample and the obtained answers

\begin{tabular}{|c|c|c|c|c|c|c|c|}
\hline Stock exchange & $\begin{array}{c}\text { Received a } \\
\text { questionnaire }\end{array}$ & $\begin{array}{l}\text { Percent of } \\
\text { total }\end{array}$ & $\begin{array}{l}\text { Responded } \\
\text { to the } \\
\text { questionnaire }\end{array}$ & $\begin{array}{l}\text { Percent of } \\
\text { responded }\end{array}$ & $\begin{array}{c}\text { Percent of } \\
\text { recieved }\end{array}$ & $\begin{array}{l}\text { Number of } \\
\text { listed } \\
\text { companies }\end{array}$ & $\begin{array}{c}\text { Number of } \\
\text { listed } \\
\text { comanies } \\
\text { per } \\
1,000,000 \\
\text { inhabitants }\end{array}$ \\
\hline (1) & (2) & (3) & (4) & (5) & $(6)=(4) /(2)$ & (7) & (8) \\
\hline Banja Luka Stock Exchange & 61 & 37.195122 & 56 & 44.8 & 91.8 & 541 & 261 \\
\hline Sarajevo Stock Exchange & 35 & 21.341463 & 27 & 21.6 & 77.1 & 315 & 261 \\
\hline Montenegro Stock Exchange & 21 & 12.804878 & 12 & 9.6 & 57.1 & 390 & 621 \\
\hline Belgrade Stock Exchange & 6 & 3.6585366 & 5 & 4 & 83.3 & 19 & 2 \\
\hline Zagreb Stock Exchange & 14 & 8.5365854 & 5 & 4 & 35.7 & 127 & 31 \\
\hline Macedonian Stock Exchange & 11 & 6.7073171 & 10 & 8 & 90.9 & 100 & 48 \\
\hline Budapest Stock Exchange & 9 & 5.4878049 & 4 & 3.2 & 44.4 & 43 & 4 \\
\hline Ljubljana Stock Exchange & 7 & 4.2682927 & 6 & 4.8 & 85.7 & 31 & 15 \\
\hline Total & 164 & 100 & 125 & 100 & 76.2 & 1,566 & - \\
\hline
\end{tabular}

(Source: Authors own calculations)

\section{RESULTS}

The largest number of respondents, $28.8 \%$ or 36 out of 125 respondents, realized the income of more than 10 million euros (Figure 1).

Figure 1: Companies per income (in $000 €$ )

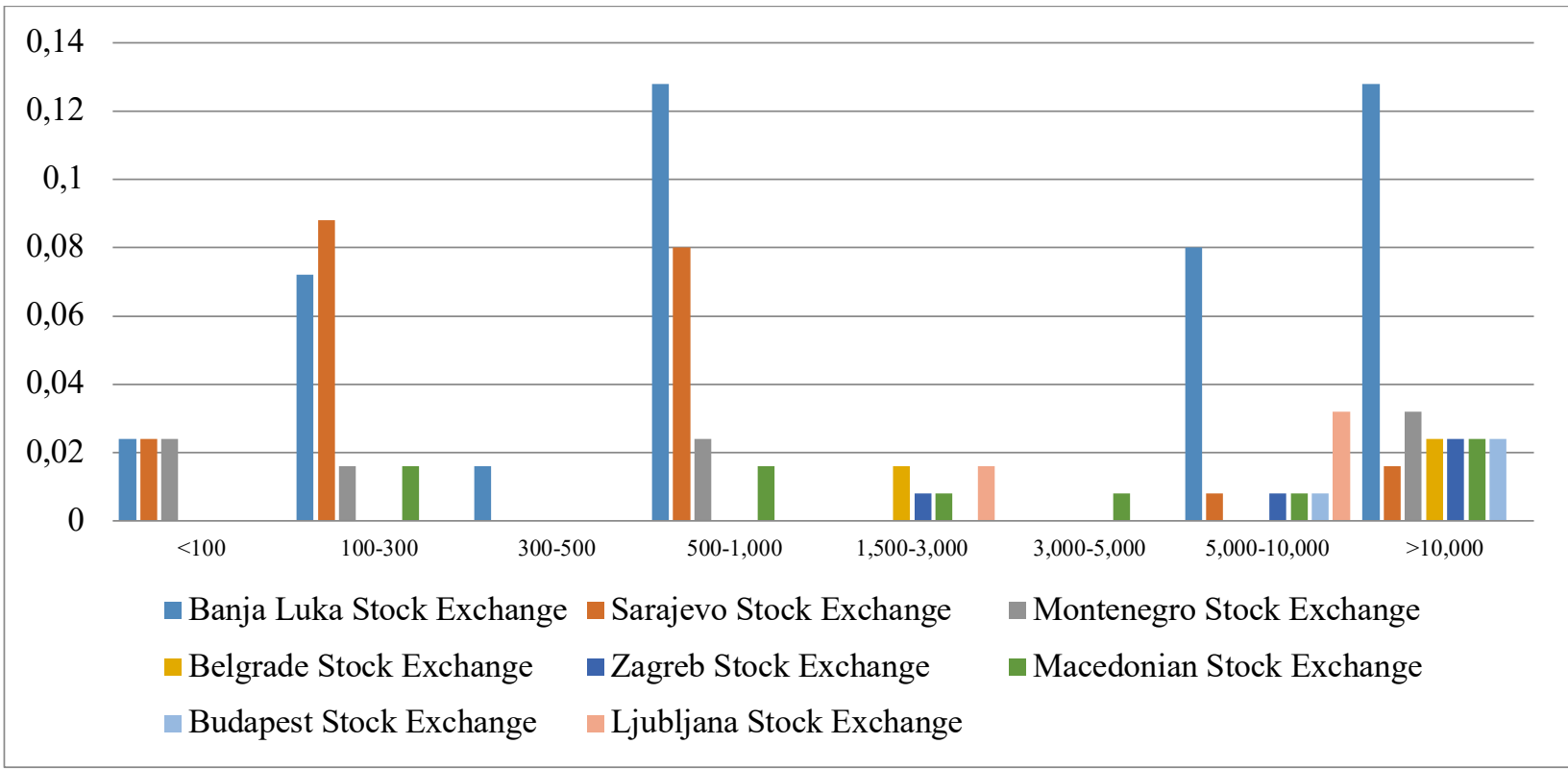

(Source: Authors own calculations)

Positive answers to the questions from the questionnaire were sorted by stock exchanges and presented in columns by ordinal numbers of questions (Table 2). 
Table 2: Cross-country differences in companies

\begin{tabular}{|c|r|r|r|r|r|r|r|r|r|r|r|r|r|r|r|r|r|r|r|r|r|}
\hline Number of question & 1 & 2 & 3 & 4 & 5 & 6 & 7 & 8 & 9 & 10 & 11 & 12 & 13 & 14 & 15 & 16 \\
\hline Banja Luka Stock Exchange & 44,64 & 26,79 & 19,64 & 50,00 & 42,86 & 37,50 & 30,36 & 39,29 & 57,14 & 51,79 & 51,79 & 26,79 & 37,50 & 37,50 & 37,50 & 64,29 \\
\hline Sarajevo Stock Exchange & 29,63 & 25,93 & 7,41 & 51,85 & 48,15 & 33,33 & 33,33 & 33,33 & 48,15 & 22,22 & 22,22 & 25,93 & 25,93 & 25,93 & 25,93 & 51,85 \\
\hline Montenegro stock exchange & 41,67 & 33,33 & 16,67 & 41,67 & 41,67 & 50,00 & 50,00 & 50,00 & 41,67 & 33,33 & 33,33 & 8,33 & 16,67 & 8,33 & 16,67 & 33,33 \\
\hline Belgrade Stock Exchange & 80,00 & 40,00 & 60,00 & 60,00 & 60,00 & 60,00 & 60,00 & 60,00 & 60,00 & 60,00 & 60,00 & 60,00 & 80,00 & 100 & 100 & 100 \\
\hline Zagreb Stock Exchange & 100 & 20,00 & 60,00 & 60,00 & 60,00 & 40,00 & 40,00 & 80,00 & 80,00 & 80,00 & 60,00 & 40,00 & 40,00 & 40,00 & 60,00 & 80,00 \\
\hline Macedonian Stock Exchange & 70,00 & 30,00 & 40,00 & 70,00 & 60,00 & 50,00 & 50,00 & 60,00 & 40,00 & 30,00 & 30,00 & 50,00 & 60,00 & 50,00 & 50,00 & 60,00 \\
\hline Budapest Stock Exchange & 100 & 50,00 & 100 & 75,00 & 75,00 & 100 & 100 & 75,00 & 75,00 & 50,00 & 50,00 & 75,00 & 100 & 75,00 & 75,00 & 75,00 \\
\hline Ljubljana Stock Exchange & 100 & 33,33 & 100 & 83,33 & 100 & 83,33 & 83,33 & 83,33 & 100 & 33,33 & 33,33 & 66,67 & 66,67 & 66,67 & 66,67 & 83,33 \\
\hline
\end{tabular}

(Source: Authors own calculations)

More than $50 \%$ of the companies listed on the Budapest Stock Exchange have the register of financial risks. Afterward, the same register have 40\%companies which are listed on the Belgrade Stock Exchange, 33.3\% listed on Montenegro, 33.3\% listed on the Ljubljana Stock Exchange, 30\% listed are listed on the Macedonian Stock Exchange, 26.8\% are tickets on the Banja Luka Stock Exchange, 25.9\% are tickets on the Sarajevo Stock Exchange and 20\% are tickets on the Zagreb Stock Exchange.

Cash flows plan on a daily basis, weekly and monthly levels have made $100 \%$ of the companies listed on the Ljubljana Stock Exchange and 100\% of the companies listed on the Budapest Stock Exchange, $60 \%$ of the companies listed on the Belgrade Stock Exchange and the Zagreb Stock Exchange, 40\% of companies that are listed on the Macedonian Stock Exchange, 19.6\% of companies that are listed on the Banja Luka Stock Exchange, $16.7 \%$ of companies that have a list on the Montenegrin Stock Exchange, 7.4\% are listed on the Sarajevo Stock Exchange.

The percentage of companies that analyzed the portfolio of current investment projects and determined the priorities and the possibility of postponing individual projects is $83.3 \%$ of companies listed on the Ljubljana Stock Exchange, 75\% of companies listed on the Budapest Stock Exchange, $70 \%$ of companies listed on the Macedonian Stock Exchange, $60 \%$ of companies listed on the Zagreb Stock Exchange, 60\% of companies listed on the Belgrade Stock Exchange, $51.85 \%$ of companies listed on the Sarajevo Stock Exchange $50 \%$ of companies listed on the Banja Luka Stock Exchange and $41.7 \%$ of companies listed on the Belgrade Stock Exchange on the Montenegro Stock Exchange.

A detailed financial stress test was performed by $100 \%$ of companies listed on the Ljubljana Stock Exchange, $75 \%$ of companies listed on the Budapest Stock Exchange, $60 \%$ of companies listed on the Macedonian, Zagreb, and Belgrade Stock Exchanges, $48.15 \%$ of companies listed on the Ljubljana Stock Exchange. listed on the Sarajevo Stock Exchange, $42.86 \%$ of companies listed on the Banja Luka Stock Exchange, and $41.7 \%$ of companies listed on the Montenegro Stock Exchange.

Key targets and success indicators for the crisis period were singled out by $100 \%$ of companies listed on the Budapest Stock Exchange, 83.3\% of companies listed on the Ljubljana Stock Exchange, 60\% of companies listed on the Belgrade Stock Exchange, and $50 \%$ of companies listed on the Macedonian Stock Exchange 50\% and on the Montenegro Stock Exchange, $40 \%$ of companies listed on the Zagreb Stock Exchange, $37.5 \%$ of companies listed on the Banja Luka Stock Exchange and 33.3\% of companies listed on the Sarajevo Stock Exchange.

All listed companies listed on the Budapest Stock Exchange believe that all employees are informed about the priorities in the crisis period. Then, the same belief in $83.3 \%$ of companies listed on the Ljubljana Stock Exchange and $60 \%$ of companies listed on the Belgrade Stock Exchange, 50\% of companies listed on Montenegro and the Macedonian Stock Exchange, 40\% of companies listed on the Zagreb Stock Exchange, $33.3 \%$ of companies listed on the Sarajevo Stock Exchange and 30.36\% of companies listed on the Banja Luka Stock Exchange. 
Five from six companies listed on the Ljubljana Stock Exchange believe that they have determined the level of operations in each of the business functions of the company, which is considered the minimum level of maintenance of the work process. Then follows $80 \%$ of companies listed on the Zagreb Stock Exchange, 75\% of companies listed on the Budapest Stock Exchange, $60 \%$ of companies listed on the Macedonian Stock Exchange and the Belgrade Stock Exchange, 50\% of companies listed on the Montenegro Stock Exchange, $39.29 \%$ of companies listed on the Banja Luka Stock Exchange and 33.3\% of companies listed on the Sarajevo Stock Exchange.

A defined model for ensuring business continuity in the event of operational risks (eg central server shutdown, power outages, accidents, and other escalations) have $100 \%$ of companies listed on the Ljubljana Stock Exchange, $80 \%$ of companies listed on the Zagreb Stock Exchange, $75 \%$ of companies listed on the Budapest Stock Exchange, 60\% of companies listed on the Belgrade Stock Exchange, 57.14\% of companies listed on the Banja Luka Stock Exchange, $48.15 \%$ of companies listed on the Sarajevo Stock Exchange, 41.67\% companies listed on the Montenegro Stock Exchange and $40 \%$ of companies listed on the Macedonian Stock Exchange.

As a direct consequence of the pandemic, workers were laid off by $80 \%$ of the companies listed on the Zagreb Stock Exchange, $60 \%$ of the companies listed on the Belgrade Stock Exchange, $51.78 \%$ of the companies listed on the Banja Luka Stock Exchange, $50 \%$ of the companies listed on the Budapest Stock Exchange, 33.3\% of companies listed on the Ljubljana Stock Exchange, 33.3\% of companies listed on the Montenegro Stock Exchange, $30 \%$ of companies listed on the Macedonian Stock Exchange and 22.22\% of companies listed on the Sarajevo Stock Exchange.

Sixty percent of the listed companies on the Belgrade and Zagreb Stock Exchanges believe that they will have to lay off workers by the end of the year, $51.79 \%$ of the companies listed on the Banja Luka Stock Exchange, 50\% of the companies listed on the Budapest Stock Exchange, 33.3\% of the listed companies. listed on the Ljubljana Stock Exchange, 33.3\% of companies listed on the Montenegro Stock Exchange, 30\% of companies listed on the Macedonian Stock Exchange.

Three out of four listed companies in Hungary believe that all employees have clear instructions on how to function during the crisis, $66.67 \%$ of companies listed on the Ljubljana Stock Exchange, $60 \%$ of companies listed on the Belgrade Stock Exchange, $50 \%$ of companies listed on On the Macedonian Stock Exchange, $40 \%$ of companies listed on the Zagreb Stock Exchange, 26.78\% of companies listed on the Banja Luka Stock Exchange, $25.92 \%$ of companies listed on the Sarajevo Stock Exchange and 8.33\% of companies listed on the Montenegro Stock Exchange.

Alternatives to permanent employment (eg alternating unpaid leave, collective leave, dismissal of temporary and occasional workers, etc.) were considered in $100 \%$ of companies listed on the Budapest Stock Exchange, $80 \%$ of companies listed on the Belgrade Stock Exchange, $66.67 \%$ of companies listed on the Ljubljana Stock Exchange, 60\% of companies listed on the Macedonian Stock Exchange, 40\% of companies listed on the Zagreb Stock Exchange, 37.5\% of companies listed on the Banja Luka Stock Exchange $25.9 \%$ of companies listed on the Ljubljana Stock Exchange on the Sarajevo Stock Exchange and $16.67 \%$ of companies listed on the Montenegro Stock Exchange.

The analysis of contracts with employees and the identification of risks that may occur in the case of some labor law activities were done in $100 \%$ of companies listed on the Belgrade Stock Exchange, $75 \%$ of companies listed on the Budapest Stock Exchange. $66.67 \%$ of companies listed on the Ljubljana Stock Exchange, 50\% of companies listed on the Macedonian Stock Exchange, 40\% of companies listed on the Zagreb Stock Exchange, 
$37.5 \%$ of companies listed on the Banja Luka Stock Exchange 25.9\% of companies listed on the Banja Luka Stock Exchange and $8.33 \%$ of companies listed on the Montenegro Stock Exchange.

The risk of leaving some key employees during or after the crisis was considered in $100 \%$ of companies listed on the Belgrade Stock Exchange, 75\% of companies listed on the Budapest Stock Exchange, $66.67 \%$ of companies listed on the Ljubljana Stock Exchange, 60\% of companies listed on the Ljubljana Stock Exchange. are listed on the Zagreb Stock Exchange, $50 \%$ of the companies listed on the Macedonian Stock Exchange, 37.5\% of the companies listed on the Banja Luka Stock Exchange, 25.92\% of the companies listed on the Sarajevo Stock Exchange and $16.67 \%$ of the companies listed on the Montenegro Stock Exchange.

Backup of all data was made in $100 \%$ of companies listed on the Belgrade Stock Exchange, 83.3\% of companies listed on the Ljubljana Stock Exchange, $80 \%$ of companies listed on the Zagreb Stock Exchange, 75\% of companies listed on the Budapest Stock Exchange, 64.29\% of companies listed on the Banja Luka Stock Exchange, 60\% of companies listed on the Macedonian Stock Exchange, 51.85\% of companies listed on the Sarajevo Stock Exchange and $33.3 \%$ of companies listed on the Montenegro Stock Exchange.

\section{DISCUSSION}

The paper presents a number of consequences that the current crisis has caused in the economy. The key consequence is a drastically reduced liquidity of all market participants, and on that basis, financial stability. However, having in mind the global character of the crisis, all the countries in the region and most of the world are facing very similar consequences for the national economy. The differences stem from the size of individual economies, and thus the losses that economies record on a daily basis.

Less than half of the companies from the Banja Luka, Sarajevo, and Montenegro stock exchanges offered positive answers to each of the questions asked. In this regard, it is obvious that there are fewer listed companies in more developed markets, but that they have better corporate governance. For example, less than half, ie $45 \%$ of the surveyed companies listed on the Banjaluka Stock Exchange, 42\% from the Montenegro Stock Exchange, and only $30 \%$ of the companies from the Sarajevo Stock Exchange analyzed different financial scenarios in business taking into account different levels of activities crisis. This data is dramatic when you consider that all surveyed companies from the Zagreb, Budapest, and Ljubljana stock exchanges have already made an analysis of different financial scenarios in business, having in mind the different levels of activity under the influence of the crisis.

It is similar with cash flow planning on a daily, weekly and monthly basis, highlighting key goals and success indicators for the crisis period, defining priorities and directing employees in the crisis period, considering alternatives to permanent employment, analyzing contracts with employees, assessing the risk of leaving key employees and make copies of all relevant data. The justification for such devastating data should be sought in the manner of privatization of state-owned enterprises. Most listed companies (utilities, veterinary stations in small local communities, etc.) on these exchanges do not meet the criteria of stock liquidity, market capitalization, and size of companies compared to companies listed on exchanges characterized by higher turnover and higher market capitalization.

\section{CONCLUSION}

The results of the research reflect the situation in the listed social regions in the region, but having in mind the stated limitations, the conclusions and results of the research should be explained. A major limitation of the research is the fact that it is not known which issuers gave certain answers to the questionnaire. In this regard, it is not possible to classify issuers except according to the criteria of the stock exchange on which they are listed. Another 
limitation of the research stems from the fact that there are fewer listed companies on larger stock exchanges and that two-thirds of the answers came from companies listed on the stock exchanges in Bosnia and Herzegovina. Namely, in $\mathrm{BiH}$, there are the most listed joint-stock companies per million inhabitants. This is the first reason why not all companies from abroad were surveyed. The results would certainly be statistically significant if we were able to collect data and evaluate a larger number of companies from all over Bosnia and Herzegovina or from the observed countries. Third, the research is primarily based on a questionnaire and reflects the perception of the respondents, there is a possibility of the actual situation to some extent the deviation of the stated opinions. In addition, we note that the response of respondents was very good (76.22 percent, or 125 out of 164), and that the sample is statistically significant in terms of the number of listed joint-stock companies by the stock exchange.

The paper presents a number of proposals in the form of issues that should encourage companies to create an integrated package of crisis measures. The speed of response in times of crisis is one of the most important factors that can affect the survival of a joint-stock company and ensure the stability of business during and after the crisis. In the deep current crisis caused by the COVID-19 virus pandemic, comprehensive and rapid support to states is necessary. The responsibility of the state for the crisis must be primarily aimed at significantly increasing the liquidity of the economy. Government support measures should use fiscal and monetary policy mechanisms and instruments. It is expected that entrepreneurs, small and medium enterprises, with the smallest liquidity stocks, will feel the consequences of economic crises the most.

Undoubtedly, the joint-stock companies on developed stock exchanges are really better prepared and have taken the crisis more seriously. Most of the positive answers were given by the companies listed on the stock exchanges in Budapest, Ljubljana, and Belgrade.

Based on the overall research, overall results, and conclusions, attitudes are made that give suggestions for assistance to joint-stock companies from foreign countries, but also for selfassessment of the joint-stock company. The future research agenda should go in this direction. Namely, the proposed questions take into account the causes of problems in listed joint-stock companies, business conditions, capital market inactivity, and macroeconomic situation because they reveal problems that occur in the process and cause self-assessments of listed joint-stock companies on stock exchanges.

The paper shows that the capital market of Bosnia and Herzegovina has an excessive number of listed equity securities created in the privatization process. It is natural that the number of "smaller" companies that are, "by force of law" - privatization, listed on the stock exchange, is declining under the influence of amended legislation. It implies that the majority owner who owns $95 \%$ of the company can buy the remaining part, change the legal form of the company, and delist it. The fallacy is the smaller number of companies means a less developed capital market.

The speed of response in times of crisis is one of the most important factors that can affect the survival of a joint-stock company and ensure business continuity after the end of the crisis. In a deep economic crisis, such as the current one caused by the COVID-19 virus pandemic, integral, comprehensive and rapid state support is primarily necessary because individual measures at the enterprise level cannot give effective results. The state's response to the crisis must be primarily aimed at significantly increasing the liquidity of the economy and restoring participants' confidence in the stability of the economic system. Government measures to support the economy must combine the mechanisms of fiscal and monetary policy in order to achieve an efficient and systematic result.

A comprehensive proposal for crisis measures at the state level is presented in detail in a previous paper. The monetary, fiscal, and parafiscal measures available to the state, the 
central bank, and the competent ministries were discussed. However, the question is whether these packages of measures will be sufficient to compensate for all the economic consequences caused by the crisis.

It is expected that entrepreneurs, small and medium enterprises, with the smallest liquidity stocks, will feel the consequences of the economic crisis the most. In addition, companies whose sales range consists of products and goods that do not include basic foodstuffs will also face significant consequences in the short and medium-term.

Regardless of size, no organization is immune to the crisis and its consequences. Therefore, crisis management must provide a rapid response to the current crisis and crisis teams have a primary role in preventing greater damage and long-term consequences. The previous paper presents a series of proposals in the form of issues that should encourage companies to create an integrated package of crisis measures. Based on questions and evaluations of the readiness of the current management system, managers can assess the gap in the quality and comprehensiveness of currently taken measures and make their company more agile more prepared for crisis response. The lessons learned from this crisis must be the subject of detailed study and translated into organizational knowledge, which would further improve the crisis management system of the company and prepare it for the new (in)normalcy.

\section{REFERENCES}

Arpan, L.M. and Roskos-Ewoldsen, D.R. (2005), "Stealing thunder: Analysis of the effects of proactive disclosure of crisis information", Public Relations Review, 31(3), pp.425-433.

Augustine, N.R. (1995), "Managing the crisis you tried to prevent", Harvard Business Review, 73(6), p.147.

Barton, L. (2001), Crisis in organizations II, college division's south-western, Cincinnati.

Carney, A. and Jorden, A. (1993), "Prepare for business-related crises", The Public Relations Journal, Vol. 49 No. 8, p.34.

Chan, S. P. (2020), "Global economy will suffer for years to come",. Available at: https://www.bbc.com/news/business-52000219

Chazan, G. (2020), "Germany tears up fiscal rule book to counter coronavirus pandemic", avalilable at: https://www.ft.com/content/dacd2ac6-6b5f-11ea-89df-41bea055720b

Coombs, W.T. (2006), Code red in the boardroom: Crisis management as organizational $D N A$, Westport, CT: Praeger.

Coombs, W.T. (2007), "Crisis management and communications", Institute for public relations, Vol. 4 No. 5, p.6.

Edward S. D. (2007), Crisis Management Planing and Execution. Auerbach Publications. Taylor \& Francis Group. Florida.

Fearn-Banks, K. (2001), Crisis communications: A casebook approach. $2^{\text {nd }}$ ed. Mahwah. NJ: Lawrence Erlbaum.

Fink, S. (1986), Crisis Management: Planning for the Inevitable. American Management Association, New York, NY.

Higgins, T. (2020), "Here's everything the federal government has done to limit the economic destruction of coronavirus.", avalilable at: https://www.cnbc.com/2020/03/23/trump-fed-congress-government-efforts-to-containcoronavirus-economic-impact.html

Hopkins, J. D. (2020), "COVID-19 Dashboard by the Center for Systems Science and Engineering (CSSE)“ at Johns Hopkins University (JHU), Washington, DC: U.S. Patent and Trademark Office. Available at: https://coronavirus.jhu.edu/map.html

Keen, S. (2020), "Thinking Exponentially about Containing the Coronavirus. Brave New Europe", available at: https://braveneweurope.com/steve-keen-thinking-exponentially-aboutcontaining-the-coronavirus 
Lončar, D., \& Stojanović, F. (2020), "Economic consequences caused by the pancemic of the covid-19 and crisis management", Journal of Contemporary Economics, 3(2). 17-32

Martyr, K. \& Mukhopadhyay, A. (2020), "Coronavirus: What countries are doing to minimize economic damage." Deutsche Welle.", avalilable at: https://www.dw.com/en/coronavirus-what-countries-are-doing-to-minimize-economicdamage/a-52816921

Milanovic, B. (2020), "The Real Pandemic Danger Is Social Collapse." Foreign Affairs Mitroff, I.I. and Harrington, L.K. (1996), "Thinking about the unthinkable". Across the board, Vol. 33 no. 8, pp. 44-48.

Paraskevas A. (2006), "Crisis management or crisisresponse system? A complexity science approach toorganizational crises “ Management Decision. Vol. 44 No. 7, pp. 892-907.

Robert, B. and Lajtha, C. (2002), "A new approach to crisis management. Journal of Contingencies and Crisis Management. Vol. 10 No. 4, pp 181-91.

Roubini, N. (2020), "This is what the economic fallout from coronavirus could look like", available at: https://www.weforum.org/agenda/2020/04/depression-global-economycoronavirus

Rudan, I. (2020). "Rudan o mjerama koje bi Hrvatska trebala poduzeti. Hrvatska radiotelevizija“, Available at:https://vijesti.hrt.hr/590346/rudan-o-mjerama-koje-bi-hrvatskatrebala-poduzeti

Worldometers. (2020), "COVID-19 Coronavirus Pandemic", Available at: https://www.worldometers.info/coronavirus/

Xuequan, M. (2020), "Unemployment in Austria hits historic high due to coronavirus pandemic", available at: http://www.xinhuanet.com/english/2020-04/02/c 138939087.html Zec, M., \& Radonjić, O. (2020), "Svet nakon koronavirus pandemije: promena razvojne paradigme ili perpetuiranje kriza“", Journal of Contemporary Economics, 3(2). 1-16 